УДК 94(437)+342.56:94(437.6)"1944/1945"+342.53

DOI: $10.24144 / 2218-5348.2019 .1-2(19-20) .9-17$

Вовканич Іван,

доктор історичних наук, професор, декан факультету історії та міжнародних відносин

Шиіцер Ігор, кандидат історичних наук, доцент ДВНЗ «Ужсгородський національний університет»

\title{
ДЕРЖАВНО-ПРАВОВЕ СТАНОВИЩЕ СЛОВАЧЧИНИ У СКЛАДІ ВІДРОДЖЕНОЇ ЧЕХОСЛОВАЦЬКОЇ РЕСПУБЛІКИ (вересень 1944 - квітень 1945 рр.)
}

У статті автори досліджують особливості державно-правового становища Словаччини у відродженій Чехословаџькій республіиі (вересень 1944 - квітень 1945 рр.). Для досягнення мети та виконання поставлених завдань вихідними принщипами роботи обрано принципи історизму та об'єктивності. На них спираються такі методи дослідження: загальнонаукового аналізу та синтезу, ретроспекиї та порівняння, описовий та моделювання.

Автори статті доходять висновку, що перехідний стан відродженої ЧСР дозволив словаџьким органам влади, передусім Словаџькій наџіональній раді, на рубежі 1944 - 1945 рр. мати відносну самостійність і дещо ширше поле законодавчої та виконавчої діяльності. Однак вона не виходила за рамки самоврядності. Особливе державно-правове становище Словаччини в складі ЧСР у ией час давало підстави розраховувати на успішне реформування союзу чеського і словацького народів на принщипі «рівний з рівним».

Ключові слова: Чехословачька республіка, Словачька наџіональна рада, Федераиія, унітарна держава, урядова програма Кошице.

In the article, the authors investigate the peculiarities of the state-legal status of Slovakia within the revived Czechoslovak Republic (September 1944 April 1945). The principles of historicism and effectiveness were applied as the main working principles to achieve and implement the goals of the research. They were supported by the following research methods: general scientific development and synthesis, retrospection and comparison, description, and modeling.

The authors of the article conclude that the transitional state of the revived Czechoslovakia led to the fact that the Slovak authorities, primarily the Slovak National Council, at the turn of 1944 - 1945 had a relative autonomy and a slightly wider field of legislative and executive activity. However, it did not go beyond self-government. The Kosice government program has become a kind of 
compromise between supporters of a federal and unitary state. The Slovak People's Republic recognized itself as a representative of the Slovak people and the bearer of state power in Slovakia. Still, the asymmetric model of the state legal system of the Czechoslovak Republic was recognized. Subsequently, by its decision of April 21, 1945, the SPR restricted its engagement somewhat, abandoning the exclusivity of its legislative and executive jurisdiction in Slovakia.

The unique state-legal position of Slovakia in Czechoslovakia at this time gave reason to count on the successful reform of the union of the Czech and Slovak peoples on the principle of "equal with equal."

Keywords: Czechoslovak Republic, Slovak National Council, Federation, unitary state, Kosice government program.

Постановка проблеми. Словацька республіка 1939 - 1945 pp. дискредитувала ідею самостійної словацької держави, а відтак наприкінці Другої світової війни виникла велика кількість різноманітних концепцій та планів щодо майбутнього державно-правового становища Словаччини. Iз вступом Червоної Армії на територію Центральної Свропи шкала можливих варіантів вирішення словацького питання звузилася до проблем, яке місце займе Словаччина у відновленій Чехословацькій республіці (ЧСР) [8, s.5,7]. I якщо словацькі політики, лідери Національного повстання 1944 p., підтримали ідею федеративного устрою держави чехів і словаків, президент ЧСР Е.Бенеш та представники чеських партій наполягали на поверненні до унітарного устрою домюнхенської республіки. Суперечки навколо цього питання зумовили особливе державно-правове становище Словаччини у відродженій республіці перехідного стану.

Аналіз останніх досліджень і публікацій. У вітчизняній історіографії державно-правове становище Словаччини в складі повоєнної ЧСР вивчали І.Вовканич, С.Пугач та І.Шніцер. У своїх працях історики констатували, що словацьке питання було однією з головних внутрішньополітичних проблем ЧСР та негативно вплинуло на чесько-словацькі відносини в державі.

Серед закордонних істориків вагомий внесок у вивчення словацького питання у повоєнній ЧСР зробили словацький історик М.Барновський, російська дослідниця В.Марьїна та чеський вчений Я.Рихлік.

Мета статті - дослідити державно-правове становище Словаччини у складі відродженої Чехословацької республіки у вересні 1944 - квітні 1945 pp.

Результати дослідження. Словацьке національне повстання 1944 р. запропонувало вельми конкретне і перспективне вирішення словацького питання. По закінченні війни мала бути відроджена ЧСР, але в жодному разі не у формі унітарної держави. Словацька національна рада (CHP) ще в грудні 1943 р. прийняла рішення, в якому говорилося: «Ми хочемо, щоб словацька і чеська нація, як найближчі слов'янські нації, поєднали свої долі в новій Чехословацькій республіці, спільній державі словаків і чехів, на основі 
принципу - рівний з рівним» [16, s.319]. Іншими словами, мова йшла про федеративну державу, у якій чехи та словаки матимуть рівні права.

Під час Словацького національного повстання 1 вересня 1944 р. була оприлюднена Декларація СНР. У ній містилася заява про те, що СНР $\epsilon$ верховним органом внутрішнього руху Опору та бере на себе роль верховного законодавчого та виконавчого органу влади в Словаччині як частини відродженої Чехословацької республіки. Також у документі відзначалося, що СНР «за братське співіснування з чеською нацією в новій Чехословацькій республіці. Конституційно-правові, соціальні, економічні та культурні питання республіки будуть взаємною угодою і остаточно вирішені обраними представниками словацького i чеського народу в дусі демократичних принципів, прогресу та соціальної справедливості» [9, s.353].

Під час повстання 1944 р. СНР проявила неабияку активність. Крім того, що вона утворила центральний орган виконавчої влади - Збір повіреників, у вересні - жовтні 1944 р. нею було видано 40 постанов, які мали силу законів.

29 вересня 1944 р. СНР прийняла спеціальну постанову про взаємовідносини з президентом Е. Бенешом та лондонським урядом ЧСР. У ній СНР заявляла, що не визнає повноваження урядового делегата на визволеній території та відмовляється передавати йому усю повноту влади на підконтрольній території. Тоді ж була сформована делегація СНР для поїздки в Лондон та принципи взаємовідносин словацьких і центральних республіканських органів влади в період визволення країни.

12 жовтня 1944 р. делегація СНР прибула до Лондона, де провела переговори 3 президентом Е. Бенешом та представниками уряду ЧСР. За підсумком переговорів була прийнята постанова. У документі зазначалося, що республіка буде національною державою рівноправних чехів, словаків та підкарпатських українців. СНР мала підтримувати зв'язок 3 президентом i лондонським урядом ЧСР через урядових делегатів. Водночас у посланні президента Е.Бенеша до СНР були визнані словаки (як нація) та наголошено, що вони повинні жити «без суперечок, непорозумінь та дискримінації» [4, с.191].

Поразка Національного повстання 1944 р. не означала відмову представників місцевого руху Опору від запропонованого членами СНР варіанту вирішення словацького питання. Після вимушеної паузи, пов'язаної 3 поразкою повстання, СНР відновила свою діяльність вже на визволеній території. 21 січня 1945 р. у м. Требішові було сформовано декілька тимчасових робочих управлінь делегації СНP [1, с.146]. Але фактичними господарями у східній частині Словаччини у цей час були радянські військові органи. Причому згідно 3 радянсько-чехословацькими домовленостями, навіть формальна передача визволених територій під управління словацьких владних органів була своєрідною - спочатку Червона Армія передавала їх під юрисдикцію уряду ЧСР, а вже той - словацькій владі. 
Про відновлення в повному обсязі юрисдикції СНP у Східній Словаччині можна твердити тільки з кінця січня - початку лютого 1945 p. Звільненими територіями Словаччини з 1 лютого 1945 р. керувала Делегація CHP. Ї̈̈ очолювали В.Шробар, Л.Новомескій, Я.Урсіні та Я.Пулл. Місцеперебуванням Делегації СНР було м. Кошице.

4 лютого 1945 p. СНР видала Маніфест про головні завдання на визволеній території. У документі наголошувалося, що «за домовленістю 3 представниками чеської нації встановимо взаємовідносини словаків і чехів у новій Чехословаччині на основі повного рівноправ'я, щоб у Словаччині словаки, а на чеських землях чехи мали свою владу, в той час як центральний сейм (парламент) і центральний уряд будуть керувати спільними питаннями єдиної та неподільної держави» [13, s.397]. Іншими словами, CHP і надалі вважала себе найвищим органом влади в Словаччині.

5 лютого була видана директива СНР про створення національних комітетів у районах i населених пунктах для підтримки громадського порядку. Показово, що СНР так і не передала владу на визволеній території урядовому делегату. Також вона дозволяла собі сперечатися 3 окремих питань iз президентом Е. Бенешом i лондонським урядом ЧСР. У протистоянні із загальнодержавним центром СНР відстоювала обмежене право на здійснення владних функцій на території Словаччини, але в рамках єдиної ЧСР. Дії словацької сторони не виходили за межі перерозподілу компетенцій між загальнодержавним центром і словацькими національнодержавними органами [1, c.152].

21 лютого 1945 р. функції найвищого словацького державного органу взяла у свої руки Президія СНР у складі Г.Гусака, Л.Новомескі, Й.Стік, Й.Шолтес, В.Шробар, Я.Урсіні [10]. На нашу думку, сумнівно говорити, що в цей час існувало повне верховенство словацьких державних органів у Словаччині. Можна говорити про елементи самоврядування у становищі Словаччини в державно-правовій системі ЧСР, яка відроджувалася.

При Делегації СНР 7 лютого 1945 р. було призначено новий (третій) склад Корпусу Уповноважених СНР [12, s.18-35]. До його складу увійшло 4 представники від Компартії Словаччини (КПС) та 9 від Демократичної партії (ДП). Коли ж Президія СНР відновила свою роль верховного органу влади у Словаччині, законодавчим актом Президії СНР №1 від 21 лютого 1945 р. було затверджено центральний виконавчий орган. У новому, четвертому складі Корпусу уповноважених СНР, який працював у період з 21 березня по 11 квітня 1945 p., у керівництві 12 міністерств нараховувалось 9 представників ДП, 7 - КПС і 1 безпартійний [1, с.147].

У березні 1945 р. Президія СНР у повному складі знаходилася в Москві на переговорах політичних партій, чеської та словацької делегацій, за участі президента ЧСР Е.Бенеша. Платформою словацької делегації для переговорів з чеськими колегами був Меморандум СНР від 2 березня 1945 p. 
У документі висувалася вимога до президента i нового уряду ЧСР визнати СНР єдиною представницею «політичної волі словацького народу, яка може виступати від імені Словаччини і вирішувати словацькі питання» [15, s.403404]. Тоді ж СНР просила підтвердити, що вона $є$ «словацьким урядом i словацьким парламентом» [15, s.403].

Однак під тиском чеських партій i КПЧ словацька сторона на московських переговорах була змушена відмовитися від головних положень Меморандуму. Згідно із спогадами Г. Гусака, лідер КПЧ К. Готвальд не хотів навіть піднімати питання про федеративний устрій. «Те, що у вас $є$ в Словаччині, збережіть, - радив К. Готвальд. - Тим самим становище словаків тимчасово вирішується. Пізніше ми побачимо, яка буде ситуація і зможемо знову повернутися до цього питання» [3, с.250].

У результаті в прикінцевих документах переговорів чеської та словацької делегацій в Москві наприкінці березня 1945 р. 3 початкових пропозицій СНР збереглося лише визнання самобутності словацького народу, будівництво взаємин між чехами і словаками в повоєнній ЧСР на принципі «рівний 3 рівним», визнання СНР як представницького органу словаків і носія державної влади в Словаччині. Показово, що розподіл компетенцій між СНР і центральними (загальночехословацькими) органами влади було відкладено на «потім». Рішення московських переговорів другої половини березня 1945 р. заперечили владно-державницькі домагання СНР. Тоді ж було відхилено й ідею про федеральний устрій ЧСР [5, с.215].

Відзначимо, що завідувач IV Європейським відділом Народного комісаріату внутрішніх справ СРСР В. Зорін, який наприкінці березня 1945 р. був призначений радянським посломув Чехословаччині, піддав гострій критиці рішення учасників московських переговорів щодо державноправового устрою ЧСР. Зокрема він заявля: «Хоч i йдеться про рівноправність чеського і словацького народів, питання державних форм i ïх подальшого існування сформовані вельми туманно: не згадується ні про автономію Словаччини, ні про федеративний союз Чехії і Словаччини» [3, c.250]. В. Зорін вважав, що «в інтересах подолання словацького сепаратизму... необхідно однозначно визначити майбутні державні форми становища Словаччини в рамках єдиної Чехословацької держави» [3, с.250].

Радянське керівництво загалом підтримувало ідею відродження ЧСР на федеративних засадах, але псувати відносини з президентом Е. Бенешом не хотіло. У майбутньому Москва планувала поширити свій вплив на всі країни Центральної Свропи, у тому числі й на чехословацьку державу [6, c.241]. Президент Е. Бенеш та представники чеських партій виступали проти особливого державно-правового становища Словаччини в ЧСР, оскільки боялися повернення словаків до ідеї створення незалежної держави й дивилися на можливу федерацію як на «слизьку платформу сепаратистських реакційних кіл Словаччини» [2, с.30]. 
3 квітня 1945 р. на територію Словаччини з Москви перемістилися загальнодержавні органи влади - уряд Національного фронту чехів і словаків на чолі з 3. Фірлінгером та президент ЧСР Е. Бенеш. А вже 5 квітня 1945 р. була оприлюднена урядова програма. У ній відзначалося, що Чехословацька республіка відроджена як «спільна держава рівноправних націй, чеської й словацької» [11, s.407], а iï уряд докладе зусиль для того, аби при конституційному оформленні відносин між словацьким і чеським народами були створені словацькі органи влади (законодавчої та виконавчої) [11, s.408].

У Кошицькій урядовій програмі відзначалося, що «Словацьку національну раду, що спирається на національні комітети в населених пунктах і районах, уряд вважатиме носієм державної влади на території Словаччини (законодавчої та виконавчої)... Спільні державні завдання центральна влада республіки буде виконувати в тісній співпраці зі СНP i Збором словацьких національних повіреників як виконавчим урядовим органом СНР» [11, s.407].

Показово, що в урядовій програмі 1945 р. були окреслені чехословацькі (федеральні) та словацькі (республіканські) інститути влади, але при цьому жодним словом не згадувалися чеські республіканські органи, що суперечило пропагованому принципу «рівний з рівним» [7, с.86]. Саме тому можемо трактувати цей документ як своєрідний компроміс: СНP визнавали репрезентантом словацького народу та носієм державної влади в Словаччині, але при цьому була закріплена асиметрична модель державноправового устрою ЧСР. Це означало, що прийняття Кошицької урядової програми не ознаменувало остаточного, і що важливіше, справедливого вирішення словацького питання в держві.

Після прийняття Кошицької урядової програми відбулася реорганізація словацьких державних органів. 7 квітня 1945 р. Президія СНР затвердила законодавче рішення №27 про організацію, структуру і принципи діяльності Корпусу уповноважених. 311 квітня 1945 р. СНР стала у повній мірі демократичним і правочинним верховним органом державної влади, котра водночас вважалася невіддільною складовою частиною ЧСР.

Особливе державно-правове становище Словаччини в складі ЧСР у перші повоєнні місяці дає підстави окремим історикам говорити про те, що Словаччина була «своєрідною напівнезалежною державою» [14, s.50]. Дійсно, у цей час словацькі органи мали відносну самостійність і дещо ширше поле законодавчої та виконавчої діяльності. Так, наприклад, члени кабінету міністрів ЧСР в особистих розмовах у квітні 1945 р. скаржилися радянському послові в Чехословаччині В.Зоріну на надмірну самостійність словацьких державних органів. Міністр внутрішніх справ ЧСР В.Носек розповідав послу СРСР, що його міністерство фактично не має можливості діяти, оскільки вся місцева державна адміністрація належить до СНР, котра претендує на виключне управління територією Словаччини. Навіть більше, зі слів міністра, словаки 
рекомендували центральному уряду займатися проблемами оборони i зовнішніми справами, а все інше полишити на СНР, «яка єдина вправі вирішувати внутрішні питання на території Словаччини» [1, с.149].

На нашу думку, відносна самостійність словацьких органів влади у цей час була обумовлена перехідним станом відродженої ЧСР та не виходила за рамки самоврядності. Так, СНР своїм рішенням від 21 квітня 1945 р. дещо обмежила власну правочинність, відмовившись від виключності своєї законодавчої та виконавчої юрисдикції у Словаччині. Також зовнішня політика і оборона були визнані компетенцією органів центральної влади.

Висновки i перспективи подальших досліджень. Словацьке національне повстання в 1944 р. започаткувало формування нової структури i системи державних органів як Словаччини, так і ЧСР у цілому. Була створена СНР як вищий державно-політичний орган та мережа національних комітетів як єдиних місцевих органів влади. Перехідний стан відродженої ЧСР призвів до того, що словацькі органи влади на рубежі 1944 - 1945 рр. мали відносну самостійність і дещо ширше поле законодавчої та виконавчої діяльності. Однак вона не виходила за рамки самоврядності. Особливе державно-правове становище Словаччини в складі ЧСР давало підстави розраховувати на успішне реформування союзу чеського і словацького народів на принципі «рівний з рівним». Відтак потребує подальшого дослідження питання, чому у повоєнні роки в ЧСР так і не вдалося вирішити словацьке питання.

\section{Список використаних джерел}

1. Вовканич I.I. Чехословаччина в 1945 - 1948 рр.: нарис історії перехідного періоду. Ужгород, 2000. 350 с.

2. Марьина В. Через «народную демократию» к социализму. 19451948 гг. // Чехия и Словакия в ХХ веке: [Очерки истории]. В 2-х кн. Кн. 2. Москва, 2005. С. 6-88.

3. Марьина В.В. Густав Гусак в Москве. 1945 // Дриновський збірник. Том IX. Софія-Харків, 2016. С. 245-253.

4. Пугач Е.П. История Словакии: монография. Харьков, 2013. 344 с.

5. Пугач Є.П. Чехо-Словацька федерація як можливість встановлення рівних прав словаків і чехів у єдиній державі (спроба реалізації та їі доля) // Вісник Харківського національного університету імені В.Н. Каразіна. Сер.: Історія. 2013. № 1087, вип. 47. С. 212-234.

6. Шніцер I. Словацьке національне питання на заключному етапі Другої світової війни (1943 - 1945 рр.) // Дриновський збірник. Том IX. Софія-Харків, 2016. С. 236-244.

7. Шніцер I. О. Три Празькі угоди як спроби вирішення словацького питання в Чехословацькій республіці (1945-1946 рр.) // Науковий вісник Ужгородського університету. Серія: Історія. 2017. Вип. 1. С. 85-89. 
8. Barnovský M. Koncepcie a variant začlenenia a štátoprávneho postavenia Slovenska (1944 - 1948) // Slovenská otázka v dejinách ČeskoSlovenska (1945 - 1992). Zbornik prispevkov z vedeckeho kolokvia, ktore sa konalo 20. oktybra 1993 / [Zost.]: Barnovsky, Michal. Bratislava, 1994. S.5-15.

9. Deklarácia Slovenskej národnej rady (1. septembra 1944) // Dokumenty slovenskej narodnej identity a štatnosti. Bratislava, 1998. Zv. I. S.353-354.

10. Delegacia pre oslobodene uzemie. SNA. F. Úrad Predsednictva SNR. Kr.254.

11. Košický vládny program (5 apríla 1945) // Dokumenty slovenskej narodnej identity a štatnosti. Bratislava, 1998. Zv. I. S. 407-409.

12. Lettrich J. Dejiny novodobého Slovenska. Bratislava, 1993. $224 \mathrm{~s}$.

13. Manifest Slovenskej národnej rady (4. februára 1945) // Dokumenty slovenskej narodnej identity a štatnosti. Bratislava, 1998. Zv. I. S.397.

14. Rychlík J. Česko-slovenský pomér v letech 1945-1969 z českého pohledu // Slovenska otazka v deinach Česko-Slovenska (1945-1992). Ed. Michal Barnovský. Bratislava, 1994. S. 50-56.

15. Uznesenie pléna Slovenskej národnej rady vo veci upravenia postavenia slovenského národa v ČSR a upravenia pomeru medzi Slovenskou národnou radou a centrálnou vládou // Dokumenty slovenskej narodnej identity a štatnosti. Bratislava, 1998. Zv. I. S. 403-406.

16. Vianočná dohoda (december 1943) // Dokumenty slovenskej narodnej identity a štatnosti. Bratislava, 1998. Zv. I. S. 319-321.

\section{REFERENCES}

1. Barnovsky M. (1994). Koncepcie a variant zaclenenia a statopravneho postavenia Slovenska (1944 - 1948) [Concepts and variants of incorporation and constitutional status of Slovakia (1944 - 1948)], Slovenska otazka v dejinach Cesko-Slovenska (1945 - 1992). Zbornik prispevkov z vedeckeho kolokvia, ktore sa konalo 20. oktobra 1993. p.5-15.

2. Deklaracia Slovenskej narodnej rady (1. septembra 1944) [Declaration of the Slovak National Council (1 september 1944)], Dokumenty slovenskej narodnej identity a statnosti. Bratislava, 1998. vol. One. p. 353-354.

3. Delegacia pre oslobodene uzemie [Delegation for the Free Territory]. SNA. F. Urad Predsednictva SNR. Kr.254.

4. Kosicky vladny program (5 aprila 1945) [Košice Government Program (5 April 1945)], Dokumenty slovenskej narodnej identity a statnosti. Bratislava, 1998. vol. I. p. 407-409.

5. Lettrich J. (1993). Dejiny novodobeho Slovenska [History of modern Slovakia]. Bratislava. 224 p.

6. Manifest Slovenskej narodnej rady (4. februara 1945) [Manifesto of the Slovak National Council (4 February 1945)], Dokumenty slovenskej narodnej identity a statnosti. Bratislava, 1998. vol. One. p.397. 
7. Marina V. (2005). Cherez «narodnuyu demokratiyu» $k$ socializmu. 1945-1948 gg. [Through "people's democracy" to socialism. 1945-1948], Chehiya i Slovakiya v XX veke: [Ocherki istorii]. V 2-h kn. Kn. 2. Moskva. p. 6-88.

8. Marina V. (2016). Gustav Gusak v Moskve. 1945 [Gustav Gusak in Moscow. 1945], Drinovskij zbirnik. vol. Ninth. Sofiya-Harkiv. p. 245-253.

9. Pugach E.P. (2013). Istoriya Slovakii [History of Slovakia].Harkiv. 344 p.

10. Pugach Ye.P. (2013). Cheho-Slovacka federaciya yak mozhlivist vstanovlennya rivnih prav slovakiv $i$ chehiv u yedinij derzhavi (sproba realizaciyi ta yiyi dolya) [Czechoslovak Federation as an Opportunity to Establish Equal Rights for Slovaks and Czechs in a Single State (attempt to implement and its fate)], Visnik Harkivskogo nacionalnogo universitetu imeni V.N. Karazina. Ser.: Istoriya. no. 1087, issue 47. p. 212-234.

11. Rychlik J. (1994). Cesko-slovensky pomer v letech 1945-1969 z ceskeho pohledu, Slovenska otazka $v$ deinach Cesko-Slovenska (1945-1992) [Czech-Slovak relationship in 1945-1969 from the Czech perspective]. Ed. Michal Barnovsky. Bratislava. p. 50-56.

12. Shnicer I. (2017). Tri Prazki ugodi yak sprobi virishennya slovackogo pitannya $v$ Chehoslovackij respublici (1945-1946 rr.) [The Three Prague Agreements as an Attempt of the Central Government to Solve the Slovak Issue in the Czechoslovak REPUBLIC (1945-1946)], Naukovij visnik Uzhgorodskogo universitetu. Seriya: Istoriya. issue 1. p. 85-89.

13. Shnicer I. (2016). Slovacke nacionalne pitannya na zaklyuchnomu etapi Drugoyi svitovoyi vijni (1943 - 1945 rr.) [Slovak National Question in the Final Stage of World War II (1943-1945)], Drinovskij zbirnik. vol. Ninth. SofiyaHarkiv. p. 236-244.

14. Uznesenie plena Slovenskej narodnej rady vo veci upravenia postavenia slovenskeho naroda v CSR a upravenia pomeru medzi Slovenskou narodnou radou a centralnou vladou [Resolution of the plenary of the Slovak National Council concerning the adjustment of the position of the Slovak nation in Czechoslovakia and the adjustment of the relationship between the Slovak National Council and the central government], Dokumenty slovenskej narodnej identity a statnosti. Bratislava, 1998. vol. One. p. 403-406.

15. Vianocna dohoda (december 1943) [The Christmas Deal (December 1943)], Dokumenty slovenskej narodnej identity a statnosti. Bratislava, 1998. vol. One. p. 319-321.

16. Vovkanich I.I. (2000). Chehoslovachchina v 1945 - 1948 rr.: Naris istoriyi perehidnogo periodu [Czechoslovakia in 1945 - 1948: Essay of Transitional Period History]. Uzhgorod. 350 p. 